\title{
MÁRIO DE ANDRADE E SILVIANO SANTIAGO: DOIS CASOS DE MEDIADORES DE CULTURA
}

\section{MÁRIO DE ANDRADE AND SILVIANO SANTIAGO:TWO EXAMPLES OF CULTURAL MEDIATORS}

\section{Maria Andréia de Paula Silva* \\ Centro de Ensino Superior de Juiz de Fora}

RESUMO: O presente artigo tem por objetivo traçar um paralelo entre Mário de Andrade e Silviano Santiago, ao partir da leitura que Santiago faz daquele como intelectual e mediador de cultura, além de sua própria postura como pesquisador contemporâneo. Pretendese mostrar como Santiago se apropria, por meio da investigação da ação através da arte, proposta por Mário de Andrade, dos métodos marioandradinos e os circunscreve sob a perspectiva da organização de um modelo intelectual na contemporaneidade.

PALAVRAS-CHAVE: Mário de Andrade. Silviano Santiago. Autoria. Circuito literário.

ABSTRACT: This paper aims at making a comparison between Mário de Andrade and Silviano Santiago, using as a starting point the reading Santiago makes of the former as an intellectual and cultural mediator, as well as considering the latter's own posture as a contemporary intellectual. We intend to show how Santiago appropriates the methods suggested by Mário de Andrade and

\footnotetext{
Possui graduação em Letras pela Universidade Federal de Juiz de Fora (1985), mestrado em Letras pela Universidade Federal de Juiz de Fora (2006) e doutorado em Estudos Literários pela Universidade Federal de Juiz de Fora (2011). Professora do Centro de Ensino Superior de Juiz de Fora, junto ao Mestrado em Letras. Juiz de Fora, Minas Gerais, Brasil. E-mail: mariaandreiasilva@pucminas.cesjf.br
} 
circumscribes them under the perspective of the organization of a contemporary intellectual model, by means of the investigation of action through art, as proposed by Mário de Andrade.

KEYWORDS: Mário de Andrade. Silviano Santiago. Authorship. Literary Circuit. 


\section{MÁRIO DE ANDRADE E SILVIANO SANTIAGO: DOIS CASOS DE MEDIADORES DE CULTURA}

\section{LIÇÃo}

Eu creio que os modernistas da Semana de Arte Moderna não devemos servir de exemplo a ninguém. Mas podemos servir de lição.

(ANDRADE, 1974, p. 255)

Antonio Candido (1992) aponta, em ensaio de 1946, ainda sob os efeitos do desaparecimento de Mário de Andrade em 1945, o papel precípuo que o autor viria a ocupar no quadro dos estudos literários futuros, principalmente quando o estudo de sua correspondência encherá volumes e será o maior monumento do gênero na língua portuguesa. $\mathrm{O}$ crítico chamava a atenção para a indistinção de valores entre cartas, ensaios e obras literárias na proposta intelectual do poeta modernista de difusão e estabelecimento de uma identidade cultural brasileira. Segundo Candido, "para ele [Mário de Andrade], escrever cartas era tarefa de tanta responsabilidade moral e literária quanto escrever poemas e estudos" (CANDIDO, 1992, p. 209). Tal responsabilidade se equacionava segundo uma dupla estratégia: a conversa e a amizade. Efetivamente, a leitura da correspondência de Mário de Andra- 
de tem propiciado aos estudiosos uma visão da ação intelectual modernista junto a novos escritores e dirigentes políticos ligados à cultura.

O exercício hermenêutico da conversa por meio de cartas permite a condição analítica, ao passo que as conversas ao pé do ouvido ou em rodas, pela impossibilidade material de se executar um mapeamento teórico e crítico, só configuram o caráter de anedota biográfica. Em "Atração pelo mundo", ensaio de 2004, Silviano Santiago aborda o que chamaremos de método de Mário de Andrade em um contexto comparativo com o processo adotado pelos autores do século XIX, notadamente Joaquim Nabuco, no qual o autor busca historicizar as estratégias políticas de globalização e de percepção da identidade na cultura brasileira.

Na parte do ensaio dedicada a Mário de Andrade, Silviano Santiago (2004a, p. 23) destaca que "pela leitura da correspondência, salta à vista o papel professoral exercido por Mário de Andrade, entregue à tarefa didática" na tentativa de caracterizar a atuação de intelectual divulgador e consolidador do modernismo que Mário de Andrade assume, principalmente no que tange ao ato de desconstrução do que o poeta paulista chama de tragédia de Nabuco. Santiago lê as cartas de Mário como parte do papel que o intelectual incorpora naquele momento, no sentido de elucidar posições e afirmar o caráter cosmopolita do movimento modernista que, nos primeiros anos, ficou circunscrito a São Paulo. O método escolhido pelo professor Mário de Andrade é mapeado pelo crítico Silviano Santiago, destacando-se alguns elementos que, no ensaio "Ora (direis) puxar conversa!” (SANTIAGO, 2006b) são retomados e utilizados para caracterizar tanto a confraternização quanto o projeto didático de Mário de Andrade.

Embora Mário de Andrade se apresente como amigo e não como professor, a forma com que se dedica a pontuar os aspectos passadistas nas posições de outros poetas, com intuito de desconstruir o culto à ideia de civilização europeia em oposição àquela de barbárie brasileira, mostra-se suficiente para qualificá-lo como tal. Soma-se a essa lição perpassada pelo modernista a reflexão que tais posições propiciavam a seus interlocutores, algo que os motivava muitas vezes a uma mudança de rumos em suas poéticas, o que nos permite vislumbrar um gesto pedagógico em ação.

Cabe aqui um esboço do que compreendemos como gesto pedagógico, pedagogia e outros termos associados. O adjetivo pedagógico tende a 
ser utilizado e interpretado, em literatura, de forma pejorativa, revelando uma desconfiança, nos meios literários, quanto a uma obra que queira dizer alguma coisa ou dos modos de leitura que privilegiem esse querer dizer, principalmente quando esse querer dizer refere-se a um ensinamento que se apresente explicitamente enquanto tal.

Essa desconfiança advém, por um lado, de teorias que supunham a rígida separação entre literatura e comunicação e, por outro, de uma concepção estreita do que se entende por logos pedagógico. Quanto à primeira desconfiança, podemos inferir que ela vem sendo superada, uma vez que as concepções que circunscrevem a literatura a uma realidade absolutamente textual têm sido questionadas, por exemplo, pela teoria da recepção ou pelos estudos que inscrevem a subjetividade autoral no texto.

Quanto à segunda, vamos nos valer da concepção de logos pedagógico descrita por Jorge Larrosa. Em seu livro Pedagogia profana o professor de filosofia da Universidade de Barcelona reflete sobre as possibilidades do processo educacional quando liberto do controle estrito do que comumente é descrito como educação.

Larrosa privilegia em sua investigação as práticas pedagógicas pelas quais se produz ou se transforma a experiência que as pessoas têm de si mesmas, seja na escola, seja no processo de análise, seja em associações de moradores. Essa percepção ampliada da ideia de prática pedagógica retira-a do espaço restrito da sala de aula e a lança no espaço do que podemos intitular "técnicas de si" ou "tecnologias do eu", conforme Michel Foucault. Para Larrosa, a "única condição é que sejam práticas pedagógicas, nas quais o importante não é que se aprenda algo 'exterior', um corpo de conhecimentos, mas que se elabore ou reelabore alguma forma de relação reflexiva do 'educando' consigo mesmo" (LARROSA, 2006, p. 36).

Em outro artigo, intitulado "A novela pedagógica e a pedagogização da novela", o professor busca pensar o que ocorre quando o texto literário é convertido em texto pedagógico submetido ao discurso didático dominante e de que modo ele escapa a esse discurso, podendo até solapá-lo.

Partindo das reflexões de Nietzsche sobre Sócrates, o autor identifica o diálogo platônico como encarnação do logos pedagógico, já que nele é possível perceber "um jogo constante de diferenças e de interferências en- 
tre níveis que, justamente porque diferem entre si, são capazes também de se interferirem e desestabilizarem mutuamente" (LARROSA, 2006, p. 120). Os diferentes níveis seriam o conteúdo a transmitir (núcleo filosófico doutrinário), o contexto empírico de transmissão (a reprodução de uma cena de conversação) e o método de transmissão (as ilustrações literárias). O diálogo, portanto, como um tecido precário e incerto revelaria a forma do logos pedagógico.

Assim, o logos pedagógico seria o que funciona por meio do jogo aberto, descentrado e possuiria três elementos que interferem entre si: a vida concreta dos protagonistas, determinada no espaço e no tempo, porém sempre plural; um jogo descentralizador de discursos heterogêneos e um impulso na direção da verdade e da justiça.

Larrosa aponta que o caráter pedagógico da literatura seria um efeito de leitura, "dado que toda ficção pode-se ler a partir do pressuposto de que contém um ensinamento que supostamente se derive de sua leitura e não esgote todas as dimensões da obra" (LARROSA, 2006, p. 129). O pedagógico seria uma modalidade de leitura aplicável a qualquer texto.

O termo logos pedagógico é utilizado aqui, portanto, nesse sentido de abertura que todo o texto possui e a lição será aquela calcada na amizade e na liberdade; amizade essa que permite a troca na comunidade de leitores e a liberdade que impulsiona a uma nova escritura. Nesse jogo é que se inscreve a pedagogia do falso que, enquanto pedagogia literária, torna-se operante em termos de práticas discursivas e não de metodologias ensináveis. Na obra de Silviano Santiago, que se equilibra entre o saber categórico e o saber em construção, tal pedagogia irá buscar no gesto escritural de Mário de Andrade suas raízes.

É nesse contexto que a leitura da postura de Mário de Andrade em oposição à de Joaquim Nabuco se faz necessária, a fim de pontuarmos as relações que diferentes gerações estabelecem quanto ao trânsito de ideias externo e interno, tema que se revela como objeto de reflexão na obra dos três intelectuais: Nabuco, Mário e Silviano.

Para tal, a metáfora da corrida de revezamento será adotada, inspirada em um texto de Silviano Santiago no qual o autor explicita seu logos pedagógico. 
Na prática intelectual, a erudição estreita do indivíduo só se robustece se disseminada pelos quatro cantos da sala de aula, concreta ou metafórica. No processo generoso de disseminação, transfere-se do outro - do mestre a quem se lê, em direção ao outro - o menos experiente a quem se ensina. Entregue aos discípulos pelo professor, a máquina do saber não deve ser alimentada por letras mortas, mas antes por força motriz, que incentiva os jovens à pesquisa de novos e mais ambiciosos caminhos de invenção. Esqueço a metáfora da camisa de sete varas e adoto outra a da corrida de revezamento.

(SANTIAGO, 2008, p. 5)

\section{CONTRAPOSIÇÃO}

Com o intento de mapear as políticas de identidade que configuram o século XX, Silviano Santiago parte das memórias de Joaquim Nabuco em Minha formação a fim de mostrar como os modernistas farão a revisão do paradigma identitário na década de 1920.

Numa perspectiva apenas aparentemente contrária aos nativistas, com seus romances fundacionais (cujo exemplo máximo é José de Alencar), Silviano Santiago percebe o movimento de tropismo definidor para Nabuco do sentido de nacionalidade. Nesse autor, haveria uma dissensão entre a ideia de país de origem e país de começo. Em resumo, a identidade é definida como origem territorial e, por isso, confunde-se com o espaço eu/terra/ nascimento. A tragédia de Nabuco, denominação atribuída por Mário de Andrade, é assim definida:

A identidade histórica de jovens nações, como as americanas, não se encontra ali onde esperam encontrá-las os nativistas, isto é, os políticos com p minúsculo. Ela está fora do tempo histórico nacional e fora do espaço pátrio: por isso é lacunar e eurocêntrica. Em resumo, o seu lugar é a 'ausência', determinada por um movi- 
mento de tropismo.

(SANTIAGO, 2004a, p. 16)

Percebe-se que a questão da identidade nacional está no cerne do problema e Silviano Santiago a lê sob o signo da saudade, definido pelo sentimento de não pertencimento, já que "remete para a ausência do Brasil na platéia da Europa quanto para a ausência da Europa na platéia brasileira" (SANTIAGO, 2004a, p. 20).

Esse mesmo sentimento de saudade é detectado por Mário de Andrade em carta do jovem poeta Carlos Drummond de Andrade, na qual o poeta mineiro declara:

Pessoalmente acho lastimável essa história de nascer entre paisagens incultas e sob céus pouco civilizados. Tenho uma estima bem medíocre pelo panorama brasileiro. Sou um mau cidadão, confesso. É que nasci em Minas, quando devera nascer (não veja cabotinismo nesta confissão, peço-lhe!) em Paris. O meio em que vivo me é estranho: sou um exilado. E isto não acontece comigo, apenas: 'Eu sou um exilado, tu és um exilado, ele é um exilado'. Sabe de uma coisa? Acho o Brasil infecto.

(ANDRADE, 2002, p. 56)

Apesar de ter cumprimentado com alegria a confissão direta e a camaradagem franca do poeta mineiro, o intelectual paulista percebe a tarefa que se afigurava: a necessidade de preencher o lugar da ausência, e o faz através da promoção e valorização do passado nacional, além do questionamento dos padrões eurocêntricos de arte.

Tal tarefa Mário levava adiante por meio da correspondência ativa com diferentes interlocutores, com os quais vai construindo sua pedagogia pela solidariedade. Esse diálogo era estabelecido segundo alguns parâmetros.

Em primeiro lugar, o tipo de linguagem utilizada por Mário de Andrade nas cartas contraria diretamente a postura da cultura de elite que, até então, 
era adotada pelos intelectuais e à qual o jovem poeta Carlos Drummond de Andrade também se aferra. Por exemplo, ao se referir à vergonha das atitudes espontâneas com a qual, segundo ele, Anatole France impregnou o pensamento dos jovens poetas brasileiros, designa-o diretamente como "filho-da-puta". É o que Silviano Santiago aponta na seguinte passagem: "A vulgaridade no linguajar do artista é marca tranquila do processo geral de desrecalque a ser operado na mentalidade vigente: as sensações e os sentimentos ao se exporem publicamente configurariam novas personalidades na cena nacional" (SANTIAGO, 2004a, p. 28).

Em segundo lugar, o método escolhido, a solidariedade através da conversa. A conversação em Mário consistia numa necessidade interior, num exercício sociopolítico e numa vontade de saber. É o que observa Silviano Santiago:

As formas da conversa (a falada, a escrita e a gestual, esta também em homem tão expansivo) são formas de um mesmo e interminável exercício e servem a uma única necessidade intelectual: a de se dialogar com todo e qualquer ser humano, numa indistinção fraterna que, se por um lado, beira o amor à humanidade, por outro, demonstra o poder social do uso público do raciocínio. A conversa, para Mário, frutifica - através de edificante e pedagógica, incontrolável e abstrata confraternização universal - uma sociedade melhor. (2006a, p. 98)

Faz parte da aprendizagem do intelectual da década de 1920 desrecalcar-se de uma forma de comportamento que tinha como parâmetro o europeu e buscar a afirmação de uma dimensão mais franca e aberta a caracterizar um traço brasileiro distinto das outras civilizações. Pela conversa, por exemplo, com "gente baixa e ignorante" (ANDRADE, 2002, p. 48) que se aprenderia a sentir e é ainda através dela que se daria a substituição da tragédia de Nabuco por uma valorização do caráter nacional, mesmo que esse gesto implique em sacrifício da promessa de eternidade por meio da obra. Mário exorta Carlos Drummond de Andrade a abrasileirar-se porque "enquanto o brasileiro 
não se abrasileirar, é um selvagem" (ANDRADE, 2002, p. 70) e porque "nós, imitando ou repetindo a civilização francesa, ou a alemã, somos uns primitivos, porque estamos ainda na fase do mimetismo" (ANDRADE, 2002, p. 71). Mário anota, também, que tal posição distancia o escritor de um lugar consagrado e o remete a uma posição insegura, angustiante, porém heroica: "Nós temos que dar ao Brasil o que ele não tem e que por isso até agora não viveu, nós temos que dar uma alma ao Brasil e para isso todo sacrifício é grandioso, é sublime. E nos dá felicidade" (ANDRADE, 2002, p. 51).

A conversa compreendida como exercício pedagógico de aprendizagem e de conversão às propostas modernistas adquire um caráter missionário que sacrifica a vaidade intelectual em função de uma inserção cotidiana na vida pública do país.

O terceiro parâmetro da pedagogia marioandradina é a percepção de que o processo de aprendizagem deveria se dar a partir da noção de erro; ou seja, sem cair no gesto anárquico da contribuição milionária de todos os erros de Oswald de Andrade, Mário de Andrade enfatiza a necessidade de aprender tudo sem distinção de valor entre alta e baixa cultura e, a partir daí, inaugurar a sabença, isto é, a ideia de que "saber saber é aprender a distinguir, depois de ter absorvido solidariamente tudo" (SANTIAGO, 2004a, p. 30). A figura eponímica dessa pedagogia seria a negra que vive a dança no carnaval carioca.

Eu conto no meu 'carnaval carioca' um fato a que assisti em plena avenida Rio Branco. Uns negros dançando o samba. Mas havia uma negra moça que dançava melhor que os outros. Os jeitos eram os mesmos, mesma habilidade, mesma sensualidade mas ela era melhor. Só porque os outros faziam aquilo um pouco decorado, maquinizado, olhando o povo em volta deles, um automóvel que passava. Ela, não. Dançava com religião. Não olhava pra lado nenhum. Vivia a dança. E era sublime. Este é um caso em que tenho pensado muitas vezes. Aquela negra me ensinou o que milhões, milhões é exagero, muitos livros não me ensinaram. Ela me ensinou a felicidade. (ANDRADE, 2002, p. 50) 
Destaque-se da citação a exortação da existência apaixonada e livre, sem prestar atenção aos outros e em oposição ao saber livresco. Essa postura assume um caráter fundamental na tarefa de afirmação de uma forma de saber distinta da postura reflexiva que, naquele momento, servia a uma crítica negativa do Brasil. A devoção quase religiosa a uma vivência é alçada a condição de parâmetro de felicidade e de sabedoria.

Cabe enfatizar que, se por um lado Mário defendia uma superação do sentimento de inferioridade perante o europeu a partir do desrecalque do sentir, por outro não deixava de destacar a necessidade de se dar um caráter sistemático e acadêmico ao projeto nacional. Eneida Maria de Souza aponta esta aparente contradição no ensaio "Preguiça e saber" (SOUZA, 1999, p. 179), a partir da caracterização de dois polos contraditórios da memória em Mário, quais sejam, o homem criativo que pressupõe a traição da memória e o sujeito público que trabalha para a preservação do patrimônio.

Ao primeiro é dado o caráter de colecionador de objetos, já que, por meio da apropriação de diversas fontes de linguagem, se esquece dos modelos e brinca "com o arquivo cultural de forma a anarquizar com sua estrutura parasitária" (SOUZA, 1999, p. 181). Ao segundo, ela atribui o papel de arquivista, que organiza a memória do país e busca modelos avançados de preservação do patrimônio oriundos da Europa.

Nesse ofício, o escritor se rende à sedução de projetos sistematizados e esquadrinhados para a construção da memória cultural brasileira. Impressiona-se, enquanto intelectual de formação autodidata, com a criação de universidades, apoiando a vinda de professores estrangeiros, dotados de instrumental técnico-científico capaz de suprir as deficiências do nosso ensino.

(SOUZA, 1999, p. 181)

Em ambos, destaca-se o intelectual Mário de Andrade na busca de construir um projeto cultural para o Brasil. Seja por meio de cartas, seja por sua atuação em órgãos governamentais, o intelectual modernista, configurado em Mário de Andrade, vê-se vanguardista e também missionário. 
Nesse sentido, nota-se que qualquer tipo de raciocínio maniqueísta impede o entendimento de sua atitude intelectual, dividida entre o saber descompromissado e macunaímico e o outro, voltado para a rigidez técnica e racional, este último, atualizado pelo projeto moderno de construção da memória nacional e da sistematização de um pensamento crítico brasileiro. As oposições se enfraquecem mediante o exame do trajeto intelectual do escritor, na medida em que se embaralham os critérios utilizados para determinar os pólos de oposição. A sua poética, calcada na preguiça, na lentidão sensual dos atos e na traição da memória, será parcialmente retomada no processo de recuperação da memória cultural do país. Persiste, contudo, a atração pela ordem e pela maturidade, verificada nos alicerces da cultura estrangeira, assim como pela pesquisa mais cuidadosa do pensamento crítico, incrementado pelo ensino universitário. (SOUZA, 1999, p. 187)

Ora, como mediar a necessidade de desconstruir o paradigma eurocêntrico de valoração das obras e a emergência de uma identidade nacional sem cair num anarquismo infrutífero? Esse dilema será administrado por Mário de Andrade por meio de outro termo de sua pedagogia: a amizade.

O ofício de escrever cartas a jovens poetas revela o dever do intelectual de orientar academicamente e de cultivar amizades que iriam constituir o fluxo das ideias modernistas e permitir sua consolidação através da conversa. A amizade permite que o intercâmbio entre mestre e discípulo não se circunscreva sob o signo da autoridade, preservando a originalidade de cada um. Mário de Andrade, por exemplo, oferta seus próprios textos à apreciação crítica dos mais jovens, como na correspondência com Carlos Drummond de Andrade, e não se furta, também, a apresentar suas ressalvas ao texto do poeta mineiro.

Portanto, a tragédia de Nabuco é efetivamente combatida por meio de um projeto pedagógico que visa ensinar aos jovens artistas brasileiros ou àqueles 
responsáveis pelos órgãos de cultura oficial o desrecalque da visão eurocêntrica de cultura com o objetivo de consolidar uma valorização de um passado nacional que, embora pequeno em relação ao passado europeu, é tão valoroso e produtivo quanto ele. Esse projeto pedagógico era colocado em prática através da escrita da obra ficcional, dos ensaios e, principalmente, das cartas.

A eleição da correspondência como forma de concretizar a solidariedade ocorre em função da própria estrutura que esse gênero textual pressupõe. A missiva só ganha circulação quando, ao ser enviada, encontra réplica, de forma que reproduz o teatro mesmo do processo de ensino. "Mestre não é quem sempre ensina, mas quem de repente aprende" (ROSA, 1986, p. 289), afirma Guimarães Rosa, e essa parece ser a configuração que a ação intelectual de Mário de Andrade assume, pois, no diálogo estabelecido através das cartas e das obras, adota alternadamente o caráter de mestre e discípulo. A figura eponímica da ação pedagógica de Mário é a negra que dança com devoção, sem olhar para os lados, convicta de sua expressão. Da mesma forma, Mário de Andrade se dedica a um processo pedagógico mais próximo, permeado pelo afeto, ciente da possibilidade de transformar o parâmetro cultural através da arte.

Para o intelectual modernista Mário de Andrade, a ação cultural deve se concretizar por meio da conversa, permeada pelo afeto e desobstruída dos parâmetros eurocêntricos propalados por Nabuco. Essa proposição é estabelecida no contexto de modernização do Brasil nos aspectos econômicos, sociais, políticos e culturais ${ }^{1}$. Cabe investigar como se configura a tarefa para o intelectual contemporâneo, como veremos a partir do próximo tópico.

1 Em Intelectuais e classe dirigente no Brasil, Sérgio Miceli (1979) afirma que "as décadas de 20, 30 e 40, assinalam transformações decisivas nos planos econômico (crise do setor agrícola voltado para a exportação, aceleração dos processos de industrialização e urbanização, crescente intervenção do estado em setores chaves da economia, etc.), social (consolidação da classe operária e da fração de empresários industriais, expansão das profissões de nível superior, de técnicos especializados e de pessoal administrativo nos setores público e privado, etc.), político (revoltas militares, declínio político da oligarquia agrária, abertura de novas organizações partidárias, expansão dos aparelhos de Estado, etc.) e cultural (criação de novos cursos superiores, expansão da rede de instituições culturais públicas, surto editorial, etc.)" (MICELI, 1979, p. xvi). 


\section{DISSEMINAÇÃO}

No ensaio denominado "Uma literatura anfíbia”, Silviano Santiago vale-se de uma metáfora para definir o caráter da literatura brasileira: "O nosso sistema literário se assemelha a um rio subterrâneo, que corre da fonte até a foz sem tocar nas margens que, no entanto, o conformam" (2004a, p. 64). Para ele, escrever e publicar numa nação de população analfabeta considerável passa a ser também uma questão política e, além disso, este escritor passa a ser um intelectual de plantão na mídia eletrônica, solicitado a explicar as ideias implícitas no livro ou a emitir opiniões no debate político.

O caráter anfíbio da literatura brasileira adviria da dupla e antípoda tônica ideológica:

O trabalho literário busca dramatizar objetivamente a necessidade de resgate dos miseráveis a fim de elevá-los à condição de seres humanos (já não digo à condição de cidadãos) e, por outro lado, procura avançar - pela escolha para personagens da literatura de pessoas do círculo social dos autores - uma análise da burguesia econômica nos seus desacertos e injustiças seculares.

(SANTIAGO, 2004a, p. 66)

Por isso, o escritor brasileiro busca configurar arte e política numa mesma obra. Silviano Santiago observa que, por seu caráter híbrido, a literatura brasileira possui dificuldade de aceitação pelo público estrangeiro; não obstante, é a afirmação de que "a contaminação" entre arte e política "é a forma literária pela qual a lucidez se afirma duplamente" (2004a, p. 69) o que distingue a literatura nacional. Além disso, a forma literária anfíbia requer uma escrita e uma leitura não inocentes que convocam tanto o autor como o leitor a um exercício de memória em construção, exigências intrínsecas ao repertório literário brasileiro.

Mais do que uma análise sobre a constituição da literatura brasileira, o ensaio destaca-se por se configurar como um texto de defesa do hibridismo da produção literária e - por que não dizer - também da produção crítica. 
Na sociedade brasileira, que só recentemente vem incluindo novas camadas sociais no circuito do saber, aqueles que têm acesso à informação e à educação também têm uma função política. É o que Mário de Andrade preconizava ao propor, através da conversa, um processo de descolonização das instâncias do saber, a fim de inaugurar um processo de sabença. É também o que Silviano Santiago parece perseguir em sua obra.

A trajetória de Silviano Santiago, enquanto professor e crítico, tem merecido simpósios e teses e, desde a publicação de Em liberdade, sua ficção, já fecunda, chamou a atenção da crítica pela proposta arrojada e claramente dependente do conhecimento teórico literário que apresentava. Em outras palavras: a ficção de Silviano Santiago tem se distinguido por mobilizar frequentemente o crítico na construção da ficção e, paralelamente, o ficcionista na elaboração do ensaio, esvaziando as operações de legibilidade que tendem a emoldurar a obra em função de um sentido único.

Em conferência proferida em 2008, na ocasião do lançamento pela Fundação Perseu Abramo e Universidade Federal de Minas Gerais do volume Leituras críticas sobre Silviano Santiago, o autor assim comenta o próprio percurso, instituindo-se a partir do lugar de trabalho: o território acadêmico.

Pequeno, embora orgulhoso, coube-me o trabalho diuturno da vida profissional como professor universitário. Generoso, embora limitado, coube-me a atividade docente junto a estudantes e colegas mais jovens, de universidades brasileiras e estrangeiras. Se o parco conhecimento literário do jovem formiguense se enriqueceu durante a formação acadêmica, acontecida nessa Universidade e na Sorbonne, acrescente-se que a moeda que satisfez sua curiosidade intelectual levou-o a contrair dívida com o aprendizado pela leitura de outros - de outros e muitíssimos escritores e intelectuais nacionais e estrangeiros. A admiração pelo trabalho do outro e a subsequente dívida de gratidão constituem um patamar de conquista da erudição individual, erudição esta que pode permanecer trancada entre 
as quatro paredes do ego, ou ser difundida a outros e muitos mais. Ao eleger a carreira em Letras Neolatinas como opção profissional, optava por semear, espalhar e difundir - em sala de aula e em letra impressa - um conhecimento consolidado pelo ensinamento dos vários e queridos professores da disciplina. A erudição pessoal se mostrava passível de transferência. Transformava-se em atos diários de generosidade e se exibia concretamente na sucessão infinita de aulas, palestras, conferências e ensaios, na orientação de quase cinqüenta teses de mestrado e de doutorado e, principalmente, no diálogo que o mais velho experiente abre com as novas gerações que chegam aos bancos acadêmicos.

(SANTIAGO, 2008, p. 3)

No fragmento de um discurso movido por agradecimento, percebem-se algumas das posições autorais assumidas por Silviano Santiago ao longo de seus textos ficcionais e críticos, tributários da sua formação de professor.

A percepção do saber como moeda de troca, tanto no recebimento quanto no pagamento da transferência, não deixa de apontar para um aspecto recorrente na obra do autor: a questão da sobrevivência do intelectual brasileiro. Como exemplo, no prefácio à correspondência de Carlos e Mário, o ensaísta destaca, entre outras, as trajetórias de ambos pelos empregos públicos que lhes rendiam tanto a moeda da sobrevivência como a da literatura.

Também é a metáfora da moeda como referência aos trânsitos entre literatura e sociedade que norteará vários textos ficcionais e críticos. Efetivamente, o posfácio ao livro de poemas Cheiro forte (1995) desenvolve essa metáfora a partir das seguintes questões: "De que moeda o poeta se vale quando entrega um poema à sociedade de leitores? Que moeda recebe ele em troca dos contemporâneos?" (SANTIAGO, 1995, p. 53).

Ao circunstanciar a circulação da poesia enquanto mercadoria, o crítico-poeta se vale de Ezra Pound para discorrer sobre a legitimação do texto poético em época de mercado. Para Pound, as afirmações gerais sobre a 
poesia são como cheques emitidos contra um banco. A validade, tanto das primeiras quanto do segundo, será determinada pelo capital acumulado de quem emite. O capital acumulado em literatura vem do saber acumulado por meio da efetiva leitura de obras do passado. Por isso, nem o senso comum, nem a atualidade teriam saber suficiente para validar o texto poético.

A legitimidade da assinatura viria da acumulação de leituras feitas pelo autor e ainda sim estas estariam comprometidas pela falsidade da moeda, já que "a usura poética negocia com o capital individual de leituras e visa ao conhecimento desinteressado" (SANTIAGO, 1995, p. 53). Silviano Santiago configura o livro de poemas como um processo de crédito e débito em relação à história da cultura humana. Para ele, a legitimação do nome que o autor assina só é possível em diferença, pois ela carrega consigo não só a do grande poeta, mas também a de todos os poetas do passado que concorrem em seus textos.

Já em $O$ falso mentiroso, a questão da influência como moeda de circulação no mercado das artes é encenada por um narrador que se apresenta como um falsário que cria, a partir de xilogravuras de Oswaldo Goeldi, cópias de tal modo perfeitas que os críticos atribuem suas telas ao pintor famoso, localizando-as, no entanto, em uma fase obscura de Goeldi. A grande ironia é a obra de Samuel ser tomada como válida apenas pela assinatura inexistente, ou seja, o anonimato passa a ser visto como um truque mercadológico. Todo o processo de criação de Samuel, ao buscar o estilo do xilogravurista, é descrito para reiterar o lugar da cópia como produção original. A criação artística passa a ser vista enquanto leitura e a literatura, essa ponte para futuro, comparece como tábua de salvação num mundo cada vez mais destituído de memória.

A possibilidade de uma memória ampliada e a definitiva derrocada da originalidade como valor artístico ganham uma formulação programática, como se constituíssem o próprio valor da arte do século XX. A percepção do domínio que um artista possui da técnica alheia e sua suplementação são prognosticadas, pelo narrador-personagem, como os valores a serem descritos pelos críticos do futuro. A tradição passa a ser vista como uma força a ser domada, numa formulação que rechaça o impulso modernista de ruptura e elege o trabalho de criação a partir das frestas que a obra acabada apresenta. 
Essa semente metafórica é o fundo comum que une os artistas brasileiros da nossa época aos de todos os tempos. [...]. A semente da produção artística é uma planície por onde planam os olhos à cata dos pequenos relevos que sobressaem, se repetem, se repetem, se repetem. Em diferença. Já disse e reitero.

(SANTIAGO, 2004b, p. 219)

Santiago, nesse romance, retoma várias de suas posições críticas consagradas tais como suas notas sobre a questão de fontes e influências e o lugar da diferença na leitura periférica. O falso mentiroso encena o exercício indistinto da criação através das palavras e advoga a posse contra a propriedade.

A constante leitura de outros autores, pressuposto da função acadêmica, comparece nas apropriações feitas pelo leitor Silviano Santiago de estilos e de temáticas de escritores que revelam tanto a admiração quanto a gratidão e se traduzem na evidente erudição que seus textos convocam, tanto iluminando o ego do autor que os assina quanto tomando a palavra do outro para difundi-la. Assim o faz, por exemplo, ao tomar a palavra de Mário de Andrade no conto "Conversei ontem à tardinha com o nosso querido Carlos" para mapear o processo de construção do movimento modernista brasileiro.

Por último, destaca-se, no fragmento da palestra proferida por Santiago na Fundação Perseu Abramo, a percepção de que aulas, artigos, publicações, orientações, entrevistas são formas encontradas pelo professor para compartilhar o que recebeu de forma generosa. Assim, Santiago agrega seu fazer literário e crítico sob o signo do exercício como professor.

Evelina Hoisel, em ensaio dedicado à obra de Silviano Santiago, destaca o que ela denomina de "espécie de lição metodológica de difusão do saber".

Sua escrita ficcional reinscreve questões teóricas e críticas, dramatizando preocupações que constituem o ideário do projeto intelectual de Silviano Santiago. Seus ensaios críticos trazem a marca do ficcionista, desdobrando temáticas, revestindo-se de outros vieses, em constante diálogo com os textos literários. Por sua vez, observa-se 
uma espécie de lição metodológica da difusão de saber em tempos midiáticos e globais, na qual um texto é apresentado inicialmente como conferência, palestra, aula, e, posteriormente, posto em circulação através de jornais - é intensa a atuação de Silviano Santiago no Jornal do Brasil e na Folha de São Paulo -, coletâneas e revistas nacionais e estrangeiras, para, finalmente, aparecer em livro de ensaios. Muitas vezes, há sucessivas recorrências a um mesmo texto e, nesse processo de apropriação e reapropriação, de migrações, as idéias vão sendo reinvestidas de outras significações dentro dos contextos discursivos para os quais migram e transmigram.

(HOISEL, 2008, p. 144)

A acuidade da observação de Hoisel quanto ao constante diálogo entre a ficção e o ensaio em Silviano Santiago pode ser observada em vários de seus romances como Viagem ao México e Em liberdade. A lição metodológica descrita, porém, nos parece ir além da difusão. Ela se afigura como um traço da escritura do autor, sem distinção dos contextos discursivos onde se realiza.

Na sequência do discurso proferido em 2008, na Fundação Perseu Abramo, Silviano Santiago desenvolve a oposição entre a ação da docência e a ociosidade do criador. Partindo da constatação da repulsa pela ética fundada no trabalho nos povos latino-americanos, mapeada por Sérgio Buarque de Holanda em Raízes do Brasil, o conferencista estabelece a relação entre o universo do professor e aquele do ócio criativo, colocando-os sob o signo da dissociação: "O professor de literatura, se também criador de arte, retira da atividade docente razão de ser e energia para a solidão e o ócio artístico" (SANTIAGO, 2008, p. 6). Tal posição reveste-se de um caráter irônico, já que faz coro com a tradicional percepção do exercício das letras como algo a ser desenvolvido de forma paralela às atividades laborais, e reinscreve a questão do mercado para a sobrevivência do escritor. Em "Vale quanto pesa", ensaio escrito em 1978 e publicado em volume homônimo de 1982, Silviano Santiago já apontava as dificuldades materiais para a existência da literatura em terras brasileiras. 
Não podendo ser profissional numa sociedade em que a sua mercadoria não circula e não é rentável, em que tampouco pode crer em dispositivos estatais ou empresariais que o amparem economicamente e em que o produto estrangeiro e concorrente é adquirido com mais constância, o escritor acaba sendo aquele que dispõe do lazer que a sua classe lhe possibilita, que as suas atividades profissionais (paralelas e rendosas) lhe proporcionam. Autor do romance que o tempo e o leitor lhe permitem. Escravo deles em suma.

(SANTIAGO, 1982, p. 28)

A “camisa de onze varas" que dá título ao discurso na fundação Perseu Abramo refere-se ao impossível lugar do criador: falar da própria qualidade da obra. A "corrida de revezamento", metáfora do papel do professor, encerra-se ao questionar a possibilidade de que o trabalho do escritor seja tributário da atuação do professor.

Em nosso entendimento, o exercício em sala de aula marca profundamente o gesto do criador e as duas atividades tornaram-se indissociáveis no processo de configuração do autor que assina Silviano Santiago. Um professor que segue uma estratégia de difusão de saber sem valoração dos contextos onde ele ocorre e cujos trânsitos, tanto pela trajetória biomaterial quanto pela produção intelectual, revelam a inquietação de um projeto em andamento, com todos os riscos em que sua pedagogia incorre.

\section{RECOLHA}

A recorrência das preocupações teórico-críticas propostas tanto pelo crítico quanto pelo ficcionista é um dado que salta aos olhos dos leitores das obras de Silviano Santiago e nas observações críticas pinçadas. As migrações e transmigrações parecem conformar a pedagogia do intelectual e esta é realizada por meio de algumas estratégias. 
Uma delas configura-se a partir da apropriação do modelo utilizado por Mário de Andrade e o insere no contexto da contemporaneidade quando as formas de difusão do saber encontram outros caminhos além da correspondência e da convivência propostas pelo escritor paulista. O puxar conversa ganha novos contornos e suportes.

Silviano Santiago puxa conversa ao frequentar as páginas dos jornais em seus cadernos de cultura, atestada em suas publicações no Jornal do Brasil, em O Globo e na Folha de São Paulo ${ }^{2}$, por exemplo. Através dos textos de intervenção ${ }^{3}$, busca aproximar-se de um público além do universitário.

Cabe destacar que o tipo de conversa que emerge da atitude de Silviano Santiago distingue-se enormemente da absorção habitualmente realizada pela mídia em relação aos meios acadêmicos. Do intelectual cuja prática distinguia-se pela "crítica daquilo que existe, o espírito livre e anticonformista, o destemor perante os poderosos, o sentido de solidariedade com as vítimas" (SARLO, 2000, p. 165), os meios de comunicação de massa inclinam-se a absorver apenas o especialista, convocado sempre a se pronunciar tão somente sobre sua área de saber, normalmente exercida na academia e devidamente circundada de seus títulos. A função atribuída aos intelectuais é a de darem seus pareceres e juízos revestidos de um caráter objetivo, já que os mass media tendem a atribuir imparcialidade à prática tecnocientífica. No entanto, quando tais pareceres e juízos ditos objetivos desses intelectuais não ecoam a opinião que está tentando ser forjada, toda essa objetividade passa a ser questionada.

Apesar de a afirmativa de Sarlo refletir certa nostalgia do intelectual latino-americano e francês dito combativo, o qual, por sua vez, reatualizou o modelo do intelectual radical do século XVIII, ela atenta para a necessidade de uma posição político-pedagógica que se oponha à hegemônica pedagogia da mídia. A tarefa do intelectual que se apresenta como um professor na mídia seria a do "dever do saber" (SARLO, 2000), ou seja, o dever de ensinar

2 Esses jornais representam um pequeno universo da ação cultural do autor. Em Leituras críticas sobre Silviano Santiago, são enumerados cerca de 144 artigos de crítica em jornais e revistas entre 1954 e 2006.

3 Textos de intervenção são entrevistas, artigos, polêmicas que colocam o intelectual numa situação de visibilidade através da mídia. 
a hierarquizar e discriminar os produtos culturais que o mercado apresenta em fluxo constante e indiscriminado.

Nesse sentido, é ilustrativo o que ocorreu com a opinião de Silviano Santiago dada à revista Veja em matéria de celebração ao mago que esta promovia. Tendo sido convocado a opinar sobre o fenômeno Paulo Coelho na França, Santiago deu a seguinte declaração:

Primeiro, é preciso desmitificar o sucesso que ele faz na França. Antes de Paulo Coelho, o grande bestseller brasileiro na França foi Meu Pé de Laranja Lima, de José Mauro de Vasconcelos. O público francês é tão medíocre ou pouco sofisticado quanto o grande público de qualquer outro país. Em segundo lugar, o fenômeno Paulo Coelho confirma a existência, hoje em dia, de um gosto globalizado e de um mercado de livros globalizado. Ele é o nosso único representante nesse mercado. (SANTIAGO apud CAMACHO, 1998)

Criticamente a resposta questionava o mito da sofisticação do público francês e enquadrava historicamente um dito fenômeno, cumprindo desta forma o que se espera de um intelectual. Porém, como tal postura não se coadunava com o caráter laudatório da reportagem, o comentário do crítico foi emoldurado sob o título de "Os críticos incrédulos".

A partir da reportagem, Santiago adquiriu a reputação de um dos mais obstinados críticos de Paulo Coelho, conforme afirmou a Revista Isto é em 2000.

Escolhido o tema, ele diz que conclui um livro em dez dias. E desdenha dos que dizem precisar de dois a três anos. 'Isso é lenda', diz, provocando a fúria de escritores e da crítica especializada. Procurado por Gente, Silviano Santiago, um de seus mais ferrenhos críticos, foi incisivo ao ser consultado sobre o que achava de Paulo Coelho como escritor. 'Não acho', limitou-se a dizer. (HONOR, 2000, p. 33) 
O episódio serve, então, para situar o tipo de conversa que Silviano Santiago tem assumido em seus textos de intervenção: a de rejeição de uma neutralidade valorativa e uma promoção do conflito de valores.

É também por meio de entrevistas que Silviano Santiago tem descrito seu processo como escritor. Em atitude similar a Mário de Andrade, quando este comenta o próprio processo de criação por meio de cartas, Santiago tem se servido dos depoimentos que concede como um espaço no qual o crítico, muitas vezes, circunscreve o ficcionista ao apontar caminhos e escolhas deste teorizados por aquele. É o que aconteceu, por exemplo, ao ser entrevistado por Carlos Eduardo Ortolan Miranda na época da publicação de $O$ falso mentiroso. Questionado sobre o paradoxo que o título encerra, Silviano Santiago discorre sobre as teorias críticas que o nortearam, circunscrevendo necessariamente a direção da leitura.

Os paradoxos que você cita, como o do título, por exemplo, é, ao meu ver, a tradução do que é literatura. 'O Falso Mentiroso', na medida em que ele tem um discurso mentiroso, mas ao mesmo tempo afirma que esse discurso é mentiroso, é uma proposição verdadeira. Então estou pedindo ao leitor que tome aquelas proposições como verdadeiras, apesar de que elas podem ser às vezes do memorialista, e podem ser por vezes do ficcionista. Mas essa, se não me engano, é a condição da memória em tempos pós-psicanalíticos. A construção da identidade, depois da psicanálise, a questão da identidade é um 'constructo', é uma constante reelaboração, como no conceito de Lacan e de Derrida de a posteriori, après court, que diz que constantemente estamos reorganizando a 'placa-mãe' da nossa memória, e essa reorganização da placa-mãe é sempre uma nova invenção de identidade que está sendo proposta. Foucault também tem uma bela passagem na 'Arqueologia do Saber' em que diz: 'Por favor, não me confundam com o retrato três por quatro, isso não é identidade’. 
Ou seja, importa é a fabulação de si mesmo, o processo de subjetivação. Portanto, existe no tipo de ficção que fiz dessa vez um processo de subjetivação que se apresenta necessariamente como fragmentário. O personagem não tem princípio, meio e fim, como tem um personagem do romance do século XIX, de Balzac. O personagem se apresenta, para retomar uma expressão de Cortázar, como um modelo para armar. (SANTIAGO apud MIRANDA, 2004, p. 3)

Destaca-se, na passagem, a voz do crítico que, ao enunciar as teorias psicanalíticas como pressupostos necessários à compreensão do personagem, ensina ao leitor o caminho a ser percorrido na trajetória da leitura. Se por um lado essa atitude revela a necessidade da educação de um leitor acostumado com uma literatura de mercado, na qual a formulação da ambiguidade do personagem se faz através do caráter ou do engano, por outro tal atitude acaba por controlar as possibilidades de leituras, ratificando umas e desqualificando outras.

Em outra direção, já agora no terreno da prática acadêmica, Silviano Santiago destacou-se por optar frequentemente pela forma ensaística.

Em "Literatura e filosofia: ensaio de reflexão", Evando Nascimento, a partir da análise de Montaigne, destaca que "o ensaio seria um exercício de reflexão em que há um investimento subjetivo, beirando os recursos da ficção, sem todavia pender exclusivamente para o imaginário, ou seja, sem abrir mão de alguma objetividade de base" (NASCIMENTO, 2010, p. 60). Tal investimento subjetivo liga-se à consciência do precário na escrita que não exaure nunca os assuntos que aborda. Essa liberdade propiciada pela escolha do gênero reflete-se na multiplicidade de temas avaliados pelo autor.

A preferência de Silviano Santiago pelo gênero ensaístico estaria ligada à ideia de uma operação hermenêutica da obra alheia que segue o movimento da vivência do crítico que evita a eleição de apenas um aspecto na percepção do objeto literário e coloca o próprio gesto crítico sempre em deslocamento.

A conversa também é estabelecida pelo enfoque interdisciplinar em seus textos. A incorporação de outras linguagens como cinema, música, televisão 
e de gêneros considerados menores como cartas e autobiografias marca uma forma de acercar-se do outro e descentralizar a fala do saber.

Outro aspecto, que está profundamente ligado ao processo de desrecalque perseguido por Mário de Andrade e que revela a profundidade do diálogo estabelecido entre Santiago e Mário, está na formulação do conceito de entre-lugar. Enunciado num ensaio da década de 1970 e de inspiração derridiana, Silviano Santiago propõe o conceito de entre-lugar para pensar as relações entre a literatura latino-americana e a europeia.

Partindo da colonização da América, o escritor localiza, na imposição do conceito de unidade renascentista, o cerne da violência da colonização. Essa se daria através da língua, do Deus, do Rei ${ }^{4}$. Para ele, a implicação maior desse movimento é a sistemática destruição dos traços originais pelo esquecimento. Como resposta a esta violência, surge a duplicação enquanto regra, já que os valores impostos pela metrópole não são assimilados e sim imitados, propiciando que, nos interstícios, a mestiçagem ${ }^{5}$ passe a destruir a unidade. Para ele, "a América Latina institui seu lugar no mapa da civilização ocidental graças ao movimento de desvio da norma, ativo e destruidor, que transfigura o elemento pronto e imutável vindo do Europeu" (SANTIAGO, 1978, p. 18). Ao retirar a ideia de passividade do movimento de trocas e ao pregar uma investida agressiva contra os modelos metropolitanos, Santiago recoloca o lugar do intelectual latino-americano como aquele que deve falar e escrever contra. Inevitavelmente, o ensaio se debruça sobre o método da crítica voltado para a análise de fontes e influências, decretando sua falência enquanto modelo de análise e denunciando a ideologia da submissão subjacente ao modelo adotado.

4 Angel Rama, em A cidade das letras, também encontra na imposição do conceito de unidade o cerne do movimento de colonização. Para ele, a organização das cidades latino-americanas faz parte da tentativa de se impor um modelo. Interessante é a observação do pensador uruguaio sobre a utopia do projeto, já que, segundo ele, este mesmo processo organizacional não conseguiu ser imposto na Europa (RAMA, 1985, p. 24).

${ }_{5}$ Serge Gruzinski, em $O$ pensamento mestiço, observa que o mimetismo pode se tornar fonte de invenções e mestiçagens. Para ele, a mestiçagem é um esforço de recomposição de um universo desagregado e um arranjo local dos novos quadros impostos pelos conquistadores (GRUZINSKI, 2001, p. 110). 
Observe-se que, para formular o conceito, o crítico se vale de posições filosóficas de origem europeia, reescrevendo-as no contexto latino-americano. Para Santiago, as influências advindas da Europa são detidamente localizadas e reescritas num movimento de retorno.

Silviano Santiago analisa o seu objeto, a saber, "o lugar que ocupa o discurso literário latino-americano frente ao Europeu” (SANTIAGO, 1978, p. 12), respaldado pelas teorias de Roland Barthes sobre a escritura e as de Jacques Derrida sobre o suplemento. Ele observa que a literatura latino-americana tem feito uso de modelos europeus lidos no seu texto escrevível e suplementados pela diferença; assim, caberia ao crítico "analisar o uso que o escritor faz de um texto, ou de uma técnica literária e se completa pela descrição da técnica que o mesmo escritor cria" (SANTIAGO, 1978, p. 22).

Mais do que tentar propor um lugar para a literatura latino-americana, o professor comparece, no ensaio, para pontuar o papel do crítico diante dela. Para ele, a literatura latino-americana daquele momento propunha um texto e abria um campo teórico, ao qual o crítico deveria estar atento. Naquele momento, na década de 1970, Santiago propõe o abandono tanto da crítica das dívidas quanto da "pseudo-marxista" (SANTIAGO, 1978, p. 28), em prol de uma crítica que "descondiciona o leitor, torna impossível sua vida no interior da sociedade burguesa e de consumo" (SANTIAGO, 1978, p. 28). Da atitude do escritor latino-americano, Santiago busca retirar uma lição de crítica.

A diferença, em relação ao texto fonte, apareceria na recusa do escritor latino-americano em trabalhar de forma espontânea, na aceitação que este faz da escritura como um dever lúcido e consciente, uma leitura nunca inocente, nas brechas da pseudounidade metropolitana.

O conceito forjado por Silviano Santiago, datado da década de 1970, aproxima-se de novas e diferentes formulações na contemporaneidade: lugar intervalar (E. Glissant), espaço intersticial (H. K. Bhabba), in-between (Walter Mignolo e Serge Gruzinski) são algumas das várias denominações para o espaço intermediário e paradoxal que se fez presente no mundo cada vez mais atravessado por turbulências ideológicas e realinhamentos globais. Segundo Núbia Jacques Hanciau, 
o desejo de releitura dos tradicionais espaços de enunciação - desafiados pelos discursos pós-colonialistas e pela posição singular da crítica ante a dependência cultural - fez com que fossem criados esses novos espaços, que, misturados às virtualidades globais e às regionalidades enunciativas, atendem ao apelo de instâncias subjetivas dos discursos em circulação.

(HANCIAU, 2005, p. 127)

Nesse sentido, a crítica dita periférica opta por formular noções que passam a atuar no sistema hegemônico, noções estas contrárias aos conceitos de totalização e unidade impostos violentamente pelo movimento colonizador.

O ensaio de Silviano Santiago pressupõe a lucidez do escritor em relação ao uso de elementos importados em seu texto e explicita o lugar do crítico e do intelectual que pode ser ocupado pelo escritor enquanto criador ou enquanto ensaísta na mudança de olhar sobre a relação entre os textos antes classificados como subalternos e metropolitanos. Para ele, o texto híbrido (ensaio e ficção) é aquele construído por um leitor.

Esse último aspecto é confirmado por outra estratégia utilizada por Silviano Santiago e que também parece estar ligada ao processo de desrecalque perseguido por Mário de Andrade: a apropriação de textos alheios, como já assinalada anteriormente. Para ele, o movimento de leitura passa necessariamente pela absorção que o sujeito faz da experiência do outro e a relê como própria. Para Antoine Compagnon, "apropriar-se seria menos tomar que se retomar, menos tomar posse de outro que de si" (COMPAGNON, 1996, p. 94). O ato de apropriação revela um leitor obcecado, que lê a experiência, pessoal e alheia, através do seu repertório de leituras: "Bons leitores são autores desprovidos de autenticidade e providos de imaginação. A lei do leitor é a do usucapião" (SANTIAGO, 2006b, p. 60). A posição do autor como leitor tem sido um recurso recorrente na literatura contemporânea, na qual tanto as posições de autor quanto as de leitor são desestabilizadas.

Ricardo Piglia assim analisa o aparecimento de cenas de leitura na literatura: 
Efetivamente, ao fixar as cenas de leitura, a literatura individualiza e designa aquele que lê, faz com que ele seja visto num contexto preciso, nomeia-o. E o nome próprio é um acontecimento, porque o leitor tende a ser anônimo e invisível. De repente o nome associado à leitura remete à citação, à tradução, à cópia, às diferentes maneiras de escrever uma leitura, de tornar visível que se leu (o crítico seria, nesse sentido, a figuração oficial desse tipo de leitor, mas evidentemente não o único nem o mais interessante). Trata-se de um tráfico paralelo ao das citações: uma figura é nomeada, ou melhor, é citada. Faz-se ver uma situação de leitura, com suas relações de propriedade e seus modos de apropriação.

(PIGLIA, 2006, p. 24)

Para Santiago, os leitores tomam posse dos textos, que não pertencem mais a seus autores. Esse procedimento, comum ao ficcionista e ao crítico, atesta tanto a erudição do autor (e o quanto ela convoca a do leitor) como aponta para a confecção de uma história da literatura brasileira feita de remissões dentro do próprio sistema literário. Tanto uma quanto outra posição são norteadas pela noção de que os laços de amizades literárias, imaginárias ou não, passam, na contemporaneidade, a substituir a tradicional metáfora familiar. No lugar de um modelo que se afirma sobre a ideia de influência e tradição, uma sugestão de teia que desconstrói os cânones oficiais através da violação, da intromissão e da apropriação. No prefácio às cartas trocadas entre Carlos Drummond de Andrade e Mário de Andrade, essas posições são criticamente situadas por Santiago.

As palavras da obra publicada em letra de imprensa são tão minhas quanto as palavras que, depois da leitura, penso em silêncio, falo ou escrevo. Os direitos do autor não são uma questão artística; pertencem antes ao contencioso legal das artes modernas. Textos literários são legados a nós, leitores, para que deles tome- 
mos posse. Podemos acrescentar a palavra alheia ao nosso vocabulário, assumir a frase lida e memorizada, incorporar a vivência do outro à nossa experiência. Ao ler, deixamos que a obra inscreva sua marca na nossa memória, ao mesmo tempo em que fincamos o marco no território que foi de um e passou a ser de todos. Ao fincá-lo, abolimos para todo o sempre o pertencimento exclusivo da obra a seu autor e à sua época.

(SANTIAGO, 2006c, p. 60)

Na proposição de Santiago, depreende-se a aproximação do crítico e do leitor. O crítico enquanto leitor é aquele que não só escreve sobre o texto, mas também se inscreve nele. Formulação coerente com as propostas contemporâneas pois, ao contrário da crítica modernista, que abolia a subjetividade do crítico e do autor em função da noção de texto enquanto elemento totalizador de sentidos, se abre para aquilo que no texto remete a um fora, que se situa mais além.

A inclusão autoral assume aqui um caráter pedagógico, ou seja, através do exemplo, o crítico convida o leitor comum a aventurar-se no terreno da análise. Trata-se de um leitor que usa a intertextualidade como uma forma de representar a fragmentação do eu e figurar a escolha a partir do afeto. Se para Barthes (2004) o ato de escrita corresponde a um tecido de citações e a intertextualidade conta uma história de leituras que aproxima a figura do autor e a do leitor em prol de uma autonomia da escritura, para Regina Zilberman a intertextualidade pode servir para a "reintrodução da história e do tempo do autor no coração de sua escrita" (ZILBERMAN, 2004, p. 93). Para o resgate da materialidade da obra e para a reinserção do sujeito na história, é necessário buscar o autor como sujeito fora do texto (cartas, fotografias, entrevistas, confissões).

Aqui se configura mais uma estratégia adotada por Silviano Santiago como intelectual contemporâneo: o sujeito que se constitui pelo desvio da leitura e da escrita do outro. Um sujeito que, ao se apropriar de tantos discursos (literários ou não), vai constituindo uma biografia e, ao mesmo tempo, revelando a necessidade de compartilhar com o leitor seu saber, sua técnica, 
seus desejos. Isso tanto para consagrar um nome ou um lugar de autoridade, o do Mestre, quanto para explicitar o quanto o outro está presente na constituição do discurso e do sujeito.

\section{DESFECHO}

Nesse artigo, procurou-se analisar a obra de Silviano Santiago, entendida em seu conjunto de produções ficcionais, teóricas e textos de intervenção, tanto em seu caráter estético quanto como um discurso que constrói o conhecimento. Para tal, atribuiu-se a esse corpus a pedagogia do falso. Ela seria estabelecida a partir do jogo constante entre saber categórico e saber em construção que toda escrita evoca, seja ficcional, seja teórica.

Estabeleceu-se a ligação entre a proposta de Silviano Santiago e a prática estabelecida por Mário de Andrade em sua correspondência, postura esta que se distinguia pela ação através da arte e que elegia a conversa como exercício hermenêutico. A metáfora roubada para caracterizar esse processo foi da corrida de revezamento, pois se os processos tinham o mesmo objetivo, a saber, estimular a reflexão sobre a cultura brasileira, os meios para a sua consecução se alteraram.

Ao afirmar o caráter anfíbio da literatura brasileira, isto é, o hibridismo entre estética e política característico da literatura nacional, Silviano Santiago deu novas conformações ao processo de desrecalque da produção artística brasileira tão caro ao autor de Macunaíma. A própria produção intelectual de Santiago se serve da forma anfíbia ao promover tanto o conhecimento quanto ao pontuar de que modo ele se processa. A indistinção entre procedimento ficcional e ensaístico que rege sua ficção aponta para a necessidade de se encenar a reflexão crítica numa moldura dramatizada que permite a percepção do processo de criação.

A constância com que aponta para a questão da sobrevivência do artista; a reflexão continuada sobre a circulação da arte no mercado; a mobilização do acervo literário e crítico; a difusão do saber através dos meios de comunicação são estratégias que parecem conformar a ação através da arte de Silviano Santiago que reorganiza a atuação do intelectual Mário de Andrade. 


\section{REFERÊNCIAS}

ANDRADE, Carlos Drummond de; ANDRADE, Mário de; SANTIAGO, Silviano. Carlos e Mário: correspondência entre Carlos Drummond de Andrade e Mário de Andrade. Rio de Janeiro: Bem-te-vi, 2002.

ANDRADE, Mário de. Aspectos da literatura brasileira. 5 ed. São Paulo: Martins Fontes, 1974.

BARTHES, Roland. O rumor da língua. Tradução de Mario Laranjeira. 2. ed. São Paulo: Martins Fontes, 2004.

CANDIDO, Antonio. Brigada ligeira e outros escritos. São Paulo: EDUSP, 1992.

CAMACHO, Marcelo. O planeta Paulo coelho. Veja, Rio de Janeiro, n. 1542, abr. 1998. Disponível em: http://veja.abril.com.br/150498/p_094.html. Acesso em: 22 abr. 2011.

COMPAGNON, Antoine. O trabalho da citação. Tradução de Cleonice P. B. Mourão. Belo Horizonte: UFMG, 1996.

GRUZINSKI, Serge. O pensamento mestiço. Tradução de Rosa Freire d’Aguiar. São Paulo: Companhia das Letras, 2001.

HANCIAU, Núbia. Entre-lugar. In: FIGUEIREDO, Eurídice (Org.). Conceitos de literatura e cultura. Juiz de Fora: UFJF, 2005. p. 125-141.

HOISEL, Evelina. Silviano Santiago e seus múltiplos. In: CUNHA, Eneida Leal (Org.). Leituras críticas sobre Silviano Santiago. Belo Horizonte: UFMG; São Paulo: Fundação Perseu Abramo, 2008. p. 143-170.

HONOR, Rosângela. Paulo Coelho briga com a Warner. Isto é gente, São Paulo, n.28, fev. 2000. Disponível em: http://www.terra.com.br/istoegente/28/reportagens/rep_paulo.htm. Acesso em: 14 abr. 2011. 
LARROSA, Jorge. Pedagogia profana: danças, piruetas e mascaradas. Tradução de Alfredo Veiga-Neto. 4. ed. Belo Horizonte: Autêntica, 2006.

MICELI, Sérgio. Intelectuais e classe dirigente no Brasil (1920 - 1945). São Paulo: Difel, 1979.

MIRANDA, Carlos Eduardo Ortolan. Literatura é paradoxo. Entrevista concedida em 13 set. 2004. Disponível em: http://pphp.uol.com.br/tropico/html/ textos/2375,1.shl. Acesso em: 22 abr. 2008.

NASCIMENTO, Evando. Matérias-primas: da autobiografia à autoficção ou vice-versa. In: NASCIF, Rose Mary Abrão; LAGE, Verônica Lucy Coutinho (Org.). Literatura, crítica e cultura IV: interdisciplinaridade. Juiz de Fora: UFJF, 2010.

PIGLIA, Ricardo. O último leitor. Tradução de Heloisa Jahn. São Paulo: Companhia das Letras, 2006.

RAMA, Angel. A cidade das letras. Tradução de Emir Sader. São Paulo: Brasiliense, 1985.

ROSA, Guimarães. Grande sertão: veredas. 20 ed. Rio de Janeiro: Nova Fronteira, 1986.

SANTIAGO, Silviano. Cheiro forte. Rio de Janeiro: Rocco, 1995.

. Uma literatura nos trópicos: ensaios sobre dependência cultural. São Paulo: Perspectiva/ Secretaria da Cultura, Ciência e tecnologia do estado de São Paulo, 1978.

. Vale quanto pesa: ensaios sobre questões político-culturais. Rio de Janeiro: Paz e Terra, 1982. 
- O cosmopolitismo do pobre: crítica literária e crítica cultural. Belo Horizonte: UFMG, 2004a.

. O falso mentiroso: memórias. Rio de Janeiro: Rocco, $2004 \mathrm{~b}$.

. As raízes e o labirinto da América Latina. Rio de Janeiro: Rocco, 2006a.

. Ora (direis) puxar conversa!: ensaios literários. Belo Horizonte: UFMG, 2006b.

. Meditação sobre o ofício de criar. Aletria, v. 18, jul-dez, 2008.

SARLO, Beatriz. Cenas da vida pós-moderna: intelectuais, arte e videocultura na Argentina. 2. ed. Rio de Janeiro: UFRJ, 2000.

SOUZA, Eneida Maria de. A pedra mágica do discurso. 2 ed. rev. e ampl. . Belo Horizonte: UFMG, 1999.

ZILBERMAN, Regina et al. As pedras e o arco: fontes primárias, teoria e história da literatura. Belo Horizonte: UFMG, 2004. 